\title{
Lagged Reserve Requirements: Implications for Monetary Control and Bank Reserve Management
}

\author{
R. ALTON GILBERT
}

\section{D}

EPOSITORY institutions meet reserve requirements imposed by the Federal Reserve by holding vault cash and reserve balances at the Federal Reserve Banks. ${ }^{1}$ Until September 1968, member banks calcuIated their required reserves based on deposit liabilities at the start of each day, for the seven days ending on Wednesdays. Reserves held to meet those requirements consisted of vault cash at the start of business over the same period, plus reserve balances at Federal Reserve Banks at the end of each day, for the seven days ending on Wednesdays. ${ }^{2}$ Thus, there was a one-day lag between the period over which deposit liabilities and vault cash were calculated and the period over which member banks held the required reserve balances, since deposit liabilities and vault cash at the start of each day are the same as those at the end of the previous day. This one-day lag allowed member banks to calculate their required reserves and reserves held as vault cash for a week before making the final adjustments to their reserve balances on Wednesdays. This system is called con-

\footnotetext{
1Legislation enacted in March 1980 imposes member bank reserve requirements on all depository institutions. Although this paper discusses the effects of reserve requirements on banks, the analysis applies also to nonbank depository institutions that are required to hold reserves with the Federal Reserve.

2Before September 1968, country member banks based their calculations of required reserves and vault cash on balances at the start of business over 14-day periods ending every other Wednesday. Reserve balances were calculated as balances at the end of each day over the same 14-day periods. In September 1968, settlement periods for country banks were shortened to one week. Another change in reserve requirements that occured in September 1968 was a liberalized carryover provision. Before that time, member banks could eliminate reserve deficiencies up to 2 percent of required reserves in one settlement period by holding additional reserves the next settlement period. Since September 1968, member banks may also carry over excess reserves of up to 2 percent of required reserves to meet reserve requirements in the next week. This paper does not consider implications of the caryover provision for monetary policy.
}

temporaneous reserve accounting (CRA) since, except for the one-day lag, assets and liabilities used in calculating reserves and required reserves are those of the same week.

In September 1968, the Federal Reserve changed the timing of reserve accounting by extending the one-day lag to a two-week lag. Under this lagged reserve accounting (LRA) system, required reserves for each settlement week (seven days ending each Wednesday) are based on deposit liabilities held two weeks earlier. Average vault cash held two weeks earlier is counted as part of reserves in the current week, and vault cash held in the current week is counted as reserves two weeks in the future. By the beginning of each reserve settlement week (Thursday through the following Wednesday), member banks know the average balances they must hold at Reserve Banks to meet required reserves for the current week. ${ }^{3}$ Table 1 describes how reserves and required reserves are calculated under both CRA and LRA.

The Federal Reserve Board adopted LRA to simplify the conduct of monetary policy and reserve man-

3 Following the end of each settlement week, member banks send reports to Reserve Banks indicating the amounts of their liabilities subject to reserve requirements and vault cash for each day of the settlement week. These reports, for the week ending each Wednesday, are due at Reserve Banks by the following Monday. Within two days after receiving these reports, Reserve Banks send statements to member banks indicating the average reserve balances they must hold during the period from Thursday through the following Wednesday. To illnstrate the timing of these reports, consider the process by which a member bank learns of its required reserve balance for the settlement week June 19m25, 1980. Required reserves for that settlement week are based upon deposit liabilities at the end of business each day June 5-11. The bank sends a report to its Reserve Bank by Monday, June 16, indicating its deposit liabilities and vault cash for the period June 5-11. By June 18 the Reserve Bank sends the member bank a statement of the daily average reserve balance the bank must hold at the end of business June 19-25 to meet reserve requirements for that period. 


\begin{tabular}{|c|c|c|}
\hline 160 & Description of relevant period & $\begin{array}{l}\text { Relevant days tor } \\
\text { setllerient week of } \\
\text { June } 10-25,1980\end{array}$ \\
\hline $\begin{array}{l}\text { Pepostl labilties } \\
\text { subject to reserve } \\
\text { requirements }\end{array}$ & $\begin{array}{l}\text { ORA average balances at the start of each } \\
\text { day tor soven days ending Weonesday } \\
\text { of the current week. }\end{array}$ & $19-25$ \\
\hline ? & 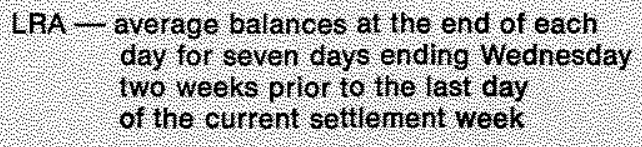 & 5.11 \\
\hline Vault cash counted as & $\mathrm{CAA} \smile$ sane as for deposil labilites & 1925 \\
\hline cuserves in the & LAA , same as tor deposit labilities & $5-11$ \\
\hline $\begin{array}{l}\text { Reservo balances. } \\
\text { counted as reserves. } \\
\text { in the current week }\end{array}$ & 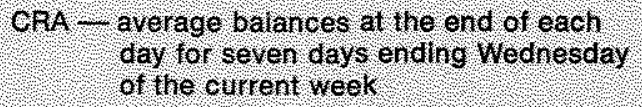 & 1025 \\
\hline & $\begin{array}{l}\text { LRA }+ \text { average balances at he end of each } \\
\text { of the current week }\end{array}$ & 1925 \\
\hline
\end{tabular}

agement by individual member banks. Because the total required reserve balances of member banks each week are known in advance under LRA, the Federal Reserve can adjust total reserve balances to the required amount in an orderly fashion throughout the week. Moreover, an individual member bank can manage its reserve position by maintaining its reserve balance at predetermined levels each week. Since LRA allows both the Federal Reserve and individual banks to know with certainty the required reserve balances for each week, it was expected to moderate fluctuations in short-term interest rates near the end of settlement weeks. According to the official statement of the Board of Governors:

"The amendments were designed to facilitate more efficient functioning of the reserve mechanism. They did not represent any change in Federal Reserve monetary policy, but were expected to reduce uncertainties, for both member banks and the Federal Reserve, as to the amount of reserves required to be maintained during the course of any reserve-computation period. Adoption of the amendments was, therefore, expected to moderate some of the pressures of reserve adjustments within the banking system that occasionally develop near the close of a reserve period and produce sharp fuctuations in the availability of daywo day funds." 4

4Board of Covernors of the Federal Reserve System, Fift $y$-fifth Annual Report of the Board of Governors of the Federal Reserve System, 1968, p. 82.
This article investigates the impact of the timing of reserve accounting on the conduct of monetary policy and on reserve management by individual banks.

\section{IMPLICATIONS OF LRA AND CRA FOR MONETARY POLICY}

\section{Effects on Variability of Money Market Conditions and Open Market Operations}

Several studies have shown that the variability of money market conditions near the end of reserve settlement periods increased after the adoption of LRA. Changes in the federal funds rate from Tuesdays to Wednesdays were greater after LRA was adopted, as were changes in the federal funds rate from week to week. Not only have short-term interest rates fluctuated more under LRA, but open market purchases and sales of securities by the Federal Reserve to stabilize short-term interest rates have also increased..$^{5}$ Thus, although the Federal Reserve has undertaken more actions to stabilize short-term interest rates since the adoption of LRA, interest rates

5Warren L. Coats, Jr, "Lagged Reserve Accounting and the Money Supply Mechanism, Joumal of Money, Credit and Banking (May 1976), pp, 167-80; William Poole and Charles Lieberman, "Improving Monetary Control," Brookings Papers on Economic Activity (1972), pp. 293-342; Albert E. Burger, The Money Supply Process (Belmont, CA: Wadsworth Publishing Co., 1971), pp. 52-56. 
have been less stable than under CRA, just the opposite of the expected outcome.

One reason for the increase in variability of shortterm interest rates and in Federal Reserve defensive open market operations is that LRA does not allow the banking system to adjust within a week to a change in total reserves by changing total required reserves. LRA predetermines required reserves for each week, based on deposit liabilities two weeks earlier. Suppose that reserves increase, causing banks to have excess reserves. If banks invest their excess reserves, demand deposit liabilities will rise in the current week, but excess reserves of the banking system will remain unchanged. Random changes in reserves under LRA, therefore, will cause either greater fluctuations in short-term interest rates or more defensive open market operations by the Federal Reserve to offset fluctuations in reserves, or both, because excess reserves or deficiencies in the current week remain regardless of actions by banks. Empirical studies indicate that, in fact, both effects have occurred.

Under CRA, if banks invest their excess reserves, their required reserves for the current week will rise as their demand deposit liabilities rise. Thus, unlike the situation under LRA, banks can eliminate a difference between total reserves and required reserves during the week.

The following illustration demonstrates differences in reserve adjustment under CRA and LRA. Suppose banks have combined balance sheets like those presented in table 2. At the beginning of a settlement week, net demand deposit liabilities are $\$ 100$; they were also $\$ 100$ two weeks earlier. Reserves of $\$ 20$ consist of $\$ 5$ in vault cash and $\$ 15$ in reserve balances; vault cash was also $\$ 5$ two weeks earlier (table 2, section $\mathrm{A}$ ). With a reserve requirement of 20 percent on demand deposit liabilities, banks are initially in equilibrium with zero excess reserves under either CRA or LRA. The remaining bank assets are invested in government securities (\$30) and loans to the nonbank public $(\$ 50)$.

Suppose that in the current settlement week demand deposit liabilities rise, as customers deposit an additional $\$ .50$ of their currency (table 2 , section $B$ ). Banks deposit the additional currency in their reserve accounts. Under CRA, banks now have excess reserves of $\$ .40$ and have an incentive to purchase securities from the nonbank public (or make additional loans) until excess reserves are reduced to zero. As each bank invests its excess reserves, demand deposit liabilities of the banking system rise by a multiple of the increase in reserves, increasing by $\$ 2$ to $\$ 102.50$ (table 2 , section $C$ ).

Under LRA, banks cannot change their required reserves of $\$ 20$ in the current week by increasing their demand deposit liabilities, since current reserve requirements are based upon deposit liabilities of two weeks earlier. If the Federal Reserve does not intervene to eliminate the excess reserves, banks will bid up the prices of securities (reducing interest rates) until they are willing to hold excess reserves of $\$ .50$. Demand deposit liabilities of the banking system would rise as individual banks invest their excess reserves. Expansion of demand deposits in the current week would be limited by a Federal Reserve policy of stabilizing short-term interest rates. If banks began bidding up the prices of securities to invest excess reserves, the Federal Reserve would eliminate the excess reserves through open market operations.

\section{Problems in Controlling Bank Reserves}

If the Federal Reserve is attempting to control growth of money by controlling bank reserves, LRA creates a more serious problem for the conduct of monetary policy than merely increasing defensive open market operations. ${ }^{6}$ The primary determinant of reserves that are supplied each week may be the deposit liabilities that the banking system created two weeks previously, rather than the objectives for money growth.

The Federal Reserve can implement monetary policy by supplying the banking system with the amount of reserves believed to be consistent with objectives for growth of monetary aggregates. Under CRA, the Federal Reserve could rely upon banks to adjust aggregate deposit liabilities to

GOne feature of LRA that promotes shortaterm control of bank reserves is that the vault cash portion of reserves is lagged. Before September 1968, the Federal Reserve did not know the amount of reserves member banks were holding each week as vault cash, since member banks did not report their vanls cash holdings to the Federal Reserve until the following week. Under ctrrent accounting procedures, the Federal Reserve can calculate the amount of vault cash counted as reserves for the current week, since member banks have reported their vault cash holdings of two weeks earlier. Member bark vault cash fluctuates so much from week to week that to reinstate counting vault cash as reserves for the same week it is held could cause substantial errors by the Federal Reserve in estimating member bank reserves in individual weeks. "Fo illustrate the potential for such error, suppose the Federal Reserve counts vault cash as reserves for the same week in which it is held and assumes that vault cash held in the current week equals that held two weeks ago (the latest information avallable). Simulating such a method of estimating reserves for each settlement week in 1976-78 indicates that errors in estimating vault cash would be more than 1 percent of total reserves for about 60 percent of the weeks, and more than 2 percent of total reserves for about 30 percent of the weeks. 


\section{Table 2}

\section{Effects of a Currency Inflow on the Banking System}

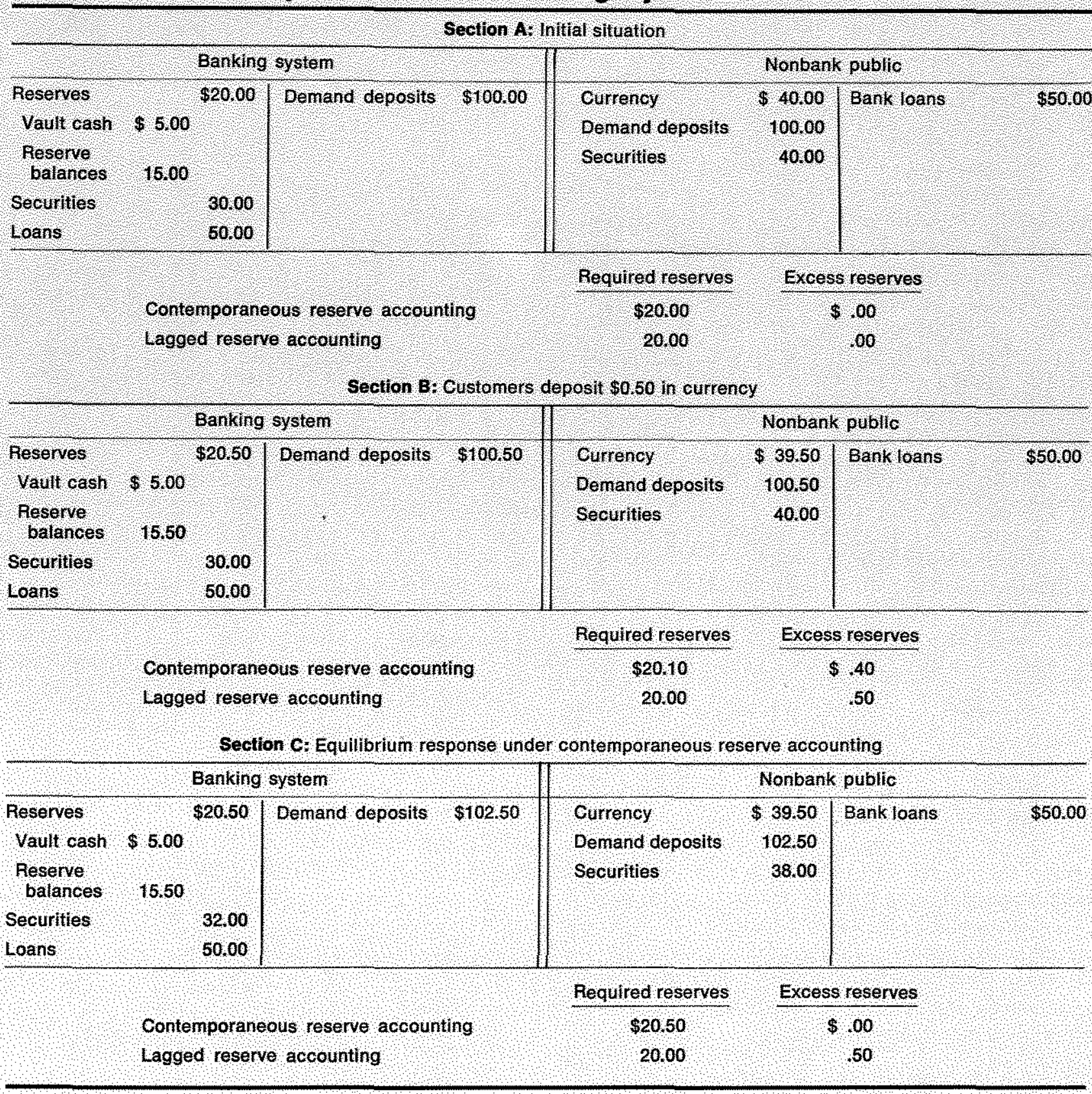

levels consistent with the amount of available reserves. If banks were to create more deposit liabilities than could be supported by available reserves, they would attempt to increase their reserves by selling securities to the nonbank public and thereby reduce deposit liabilities of the banking system to a level which could be supported by total available reserves. ${ }^{7}$
TThe ability of the Federal Reserve to control growth of the money stock by controlling bank reserves may be limited, since banks may borrow reserves at the discount window. If for instance, demand for credit increases but the Federal Reserve keeps nonborrowed reserves unchanged, banks could accommodate the increase in credit demand by creating additional demand deposit liabilities, and borrow the additional reserves necessary to meet the higher required reserves. This article assumes that the Federal Reserve is capable of controlling total bank reserves weekly; thus the analysis can focus on how the timing of reserve accounting affects the conduct of 
Table 3

\section{Response of the Banking System to an Increase in Loan Demand}

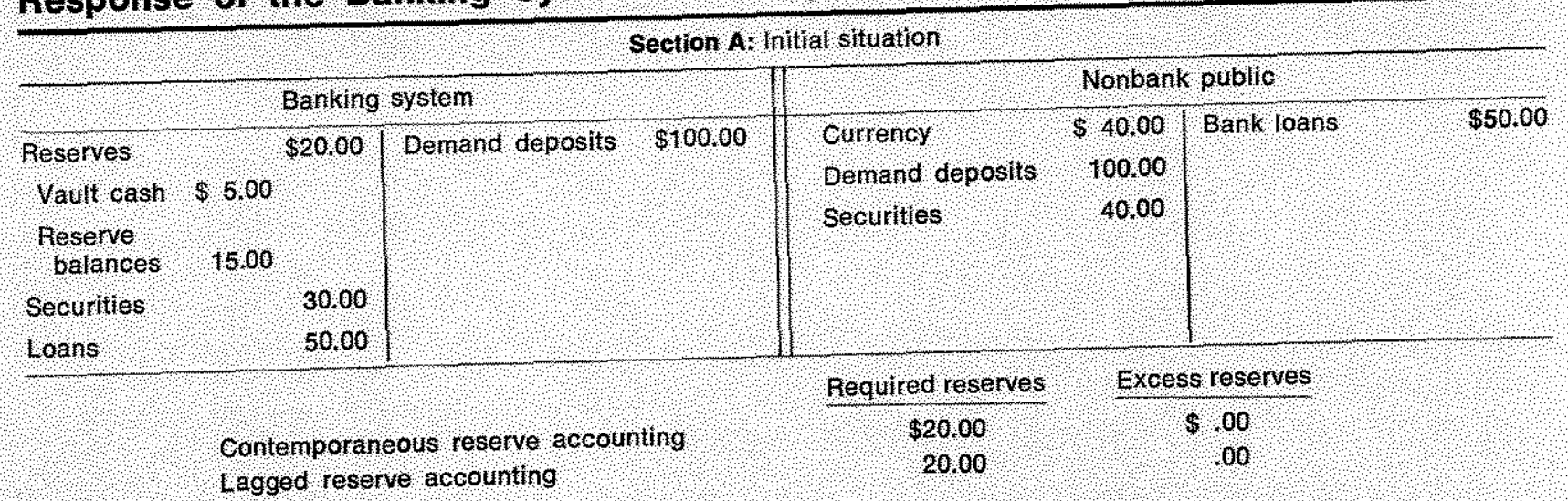

Section B. Initial response to increase in loan demand

\begin{tabular}{|c|c|c|c|c|}
\hline & & Banking & systen & \\
\hline neserves & & $\$ 20,00$ & benand deposits & $\$ 10200$ \\
\hline Vaut cash & $\$ 500$ & & & \\
\hline $\begin{array}{l}\text { Reserve } \\
\text { balances }\end{array}$ & 15.00 & & & \\
\hline Secuitiles & & 30.00 & & \\
\hline Loans & & 5200 & & \\
\hline
\end{tabular}

Contemporaneous reserve accounting

\begin{tabular}{|c|c|c|}
\hline currency & $\$ 40.00$ & Bank loa: \\
\hline Detrand deposits & 10200 & \\
\hline Securities & 4000 & \\
\hline Required reserves & \multicolumn{2}{|c|}{ Excess reserves } \\
\hline $3,820.40$ & & 40 \\
\hline 20.00 & & 800 \\
\hline
\end{tabular}

Lagged reserve accounting

Section C. Equilibrium response under contemporaneous reserve accounting

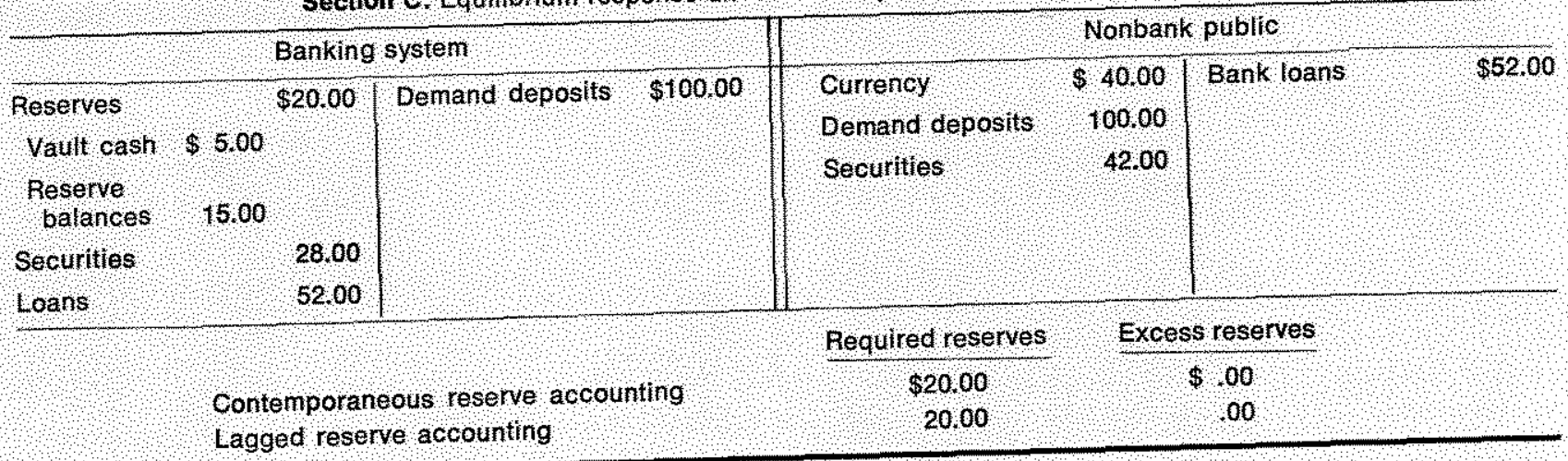

Adjustment of the banking system to reserves supplied by the Federal Reserve under CRA is illustrated in table 3 . The banking system is initially in equilibrium with zero excess reserves: net demand deposit liabilities are $\$ 100$ and, with a 20 percent reserve requirement, reserves are $\$ 20$ (table 3 , section $\mathrm{A}$ ).

monetary policy without lengthy discussion of the Federal Reserve's ability to predict or offset various factors that affect hese total reserves. One way to mininize chang be to set the discount ings from the discont warket interest rates.
Banks respond to a $\$ 2$ increase in demand for loans by the nonbank public by increasing their loans and demand deposit liabilities by $\$ 2$ (table 3 , section $B$ ). Required reserves are now $\$ 20.40$, whereas available reserves are only $\$ 20$. The Federal Reserve keeps reserves at $\$ 20$ to meet the objective for money growth. Banks must eliminate deficiencies that are developing in their reserve positions by reducing required reserves. One approach involves selling securities to the nonbank public to increase their reserves, 
thereby reducing demand deposit liabilities of the banking system. The reserve deficiency is eliminated when banks sell $\$ 2$ of their securities, because demand deposits are reduced back to $\$ 100$ (table 3, section C). After making this final adjustment, banks have accommodated the increase in loan demand by selling securities, without changing demand deposit liabilities. $^{8}$

LRA breaks the link between reserves available to the banking system in the current week and the amount of deposit liabilities that banks can create in the current week. If banks increase aggregate demand deposit liabilities in response to an increase in loan demand, they are under no immediate pressure to reduce their deposit liabilities, since excess reserves remain unchanged at zero. Therefore, in the hypothetical situation presented in table 3, LRA permits banks to keep total demand deposit liabilities at $\$ 102$ in the current week without reserve deficiencies.

Two weeks later, required reserves would equal $\$ 20.40$, reflecting the $\$ 2$ increase in demand deposits. If the objective of monetary policy is to keep total reserves unchanged at $\$ 20$, this situation poses a dilemma for the Federal Reserve. Keeping reserves unchanged at $\$ 20$ would produce a sharp increase in short-term interest rates, as banks attempt to meet their required reserves. Despite the rise in interest rates, some banks would have deficient reserve positions, since they could not alter their required reserves for the week by selling securities. Unless the Federal Reserve would be willing to permit these large fluctuations in short-term interest rates and reserve defciencies by some banks, it would have to provide the additional reserves.

The Federal Reserve would also be under pressure to reduce reserves two weeks after a decline in deposit liabilities. Unless the Federal Reserve would reduce reserves when required reserves declined, attempts by the banking system to invest the excess reserves would reduce short-term interest rates to levels at which some banks would be willing to hold the excess reserves.

In summary, the most important implication of the timing of reserve requirements for monetary control is that under CRA the Federal Reserve could pro-

\footnotetext{
$8 \mathrm{~A}$ bank can increase its reserves and thereby reduce demand deposit liabilities of the banking system other than by selling securities to the ronbank public. For instance, it can sell certificates of deposit. Customers buying certificates of deposit pay for them with demand deposits. In the process, demand deposit liabilities of the banking system decline. This approach to eliminating reserve deficiencies is more complicated than that described in table 3 (selling securities to the nonbank public), since certificates of deposit are subject to reserve requirements. The example of banks selling securities was selected for expositional convenience only.
}

vide the level of reserves each week that would be consistent with targets for monetary aggregates, and banks would adjust their deposit liabilities to available reserves. Under LRA, the Federal Reserve tends to adjust total reserves each week in response to the total deposit liabilities that banks created two weeks earlier:

If LRA creates such difficulties for monetary control, why has the Federal Reserve tolerated it since 1968 ? One reason is that many member bankers prefer LRA. The Federal Reserve has been reluctant to initiate an unpopular change that might accelerate membership attrition. This consideration is less important now since recent legislation extends member bank reserve requirements to nonmember depository institutions.

Another reason that LRA has not been abandoned is that it does not create significant problems for monetary control if the Federal Reserve implements monetary policy by targeting on the federal funds rate. Until October 6, 1979, the Federal Reserve conducted open market operations to keep the federal funds rate within ranges that were presumed to be consistent with monetary growth objectives. Monthly ranges for movements of the federal funds rate were rather narrow, generally within 50 to 100 basis points. Many of the influences that could change bank reserves, such as changes in the public's demand for currency or Federal Reserve float, were offset by targeting open market operations on the federal funds rate. The Federal Reserve attempted to control monetary growth by adjusting short-term interest rates to levels at which the amount of money demanded by the public equalled the desired levels for the monetary aggregates. ${ }^{10}$ With the emphasis on response of money demand to changes in short-term interest

9There is evidence that the Federal Reserve, since adopting LRA, has adjusted member bank reserves to the deposit liabilities member banks created two weeks earlier. Feige and MeGee estimated the relation between the money stock and bank reserves for a peziod before and a period after September 1968. For the period before September 1968, the money stock (with autocomrelations removed) was most highly cor related with reserves in the same week. However, for the period after September 1968, the money stock was most highly correlated with reserves two weeks in the future. See Edgar L. Feige and Robert McGee, "Money Supply Control and Lagged Reserve Accounting," Journal of Money, Credit and Banking (November 1977), pp. 536-5l. In another study, using data for a period after September 1968 , monthly money stock, with antocorrelations removed, was most highly correlated with reserves in the same month and in the next month. See David A. Pierce, "Money Supply Control: Reserves as the Instrument Under Lagged Accounting," Journal of Finance (June 1976), pp. 845-52.

10For a description of this approach to implementing monetary policy, see Henry C. Wallich and Peter M. Keir, "The Role of Operating Guides in U.S. Monetary Policy: A Historical Review," Federal Reserve Bulletin (September 1979), pp. 679-91. 
rates rather than on response of money supply to reserves, difficulty in controlling money by controlling reserves under LRA was not considered an important issue for monetary policy. ${ }^{11}$

Implementing monetary policy by targeting on the federal funds rate has created serious problems for monetary control. Because the Federal Reserve has attempted to moderate changes in short-term interest rates, monetary aggregates have responded positively to changes in demand for money and credit. When credit demand has risen, for instance, the Federal Reserve has not raised its targets for the federal funds rate fast enough to avoid supplying additional reserves, and banks have accommodated increases in credit demand by creating additional demand deposits. Conversely, when demand for credit has declined, the Federal Reserve has attempted to moderate declines in short-term interest rates and, in the process, has reduced the supply of reserves.

Because targeting on the federal funds rate resulted in money growth that was too rapid to stay within desired ranges for money growth, the Federal Reserve adopted a reserve targeting approach to implementing monetary policy on October 6, 1979. The Federal Reserve now establishes targets for growth of a group of bank reserve aggregates that are presumed to be consistent with objectives for growth of monetary aggregates. Under this system, the federal funds rate is allowed to fluctuate within a relatively wide range. Although the Federal Reserve has not completely abandoned the objective of confining fluctuations in short-term interest rates, it is placing more emphasis on controlling bank reserves. ${ }^{12}$ Under this recently adopted policy of reserve targeting, problems of controlling growth of bank reserves inder LRA are more important for monetary policy.

\section{IMPLICATIONS OR LRA AND CPA POP PQRERVE MANAGEMENT OF TNDVWDUAT, BANKS}

\section{Montoring Deposit Libbihnes}

One reason for adopting LRA was to simplify reserve management for individual banks. Under LRA,

\footnotetext{
11Kopecky develops a theoretical model in which LRA does not create problems for money stock control if the Federal Reserve implements monetary policy by targeting on the federal funds rate. See Kenneth J. Kopecky, "The Relationship Between Reserve Ratios and the Monetary Aggregates Under Reserves and Federal Funds Rate Operating Targets," Staff Economic Stzdies No. 100, Board of Governors of the Federal Reserve System, 1978 .

${ }^{12}$ Richard W. Lang, "The FOMC in 1979: Introducing Reserve Targeting," this Review (March 1980), pp. 2-25.
}

each bank is notified before the beginning of a settlement week concerning the daily average reserve balance necessary to meet its reserve requirements for the week. This procedure allows a member bank to focus its attention on holding predetermined levels of average reserve balances. In contrast, under CRA, each bank had to monitor closely its deposit liabilities and adjust its reserves to meet requirements based on those deposits each week, More timely monitoring of deposit liabilities and adjusting reserves to expected required reserves involve some costs to banks under CRA.

\section{Estmalng Required Reserves}

Many banks would have difficulty determining their required reserves for each settlement week under CRA, even with more timely monitoring of deposit liabilities. Some banks, particularly those with branches, compile information on their deposit liabilities one or two days after the end of each settlement week. Many small banks have check processing centers perform their accounting functions, and they receive information on their deposit liabilities with a lag of one or two days.

Consequently, these banks' estimates of their required reserves would be based on incomplete information concerning their weekly deposit liabilities. Errors in calculating required reserves due to incomplete information on deposit liabilities would result in excess reserves or deficiencies.

Whether incomplete information would create major problems for reserve management under CRA is an empirical question. Banks may carry over excess reserves or deficiencies, up to 2 percent of required reserves, into the next settlement week without penalties or loss of credit for excess reserves. Estimating required reserves using incomplete information on deposit liabilities would not create serious problems for reserve management if estimated required reserves were always within 2 percent of actual required reserves. ${ }^{13}$

13 This section analyzes the magnitude of differences between estimated and actual required reserves for individual banks that would tend to occur on a weekly basis under CRA due to incomplete information on deposit liabilities for each settlement week. This factor would be important under CRA, but not under LRA, since individual banks know their required reserve balances for each settlement period at the stat of the period. Another factor that tends to make a bank's reserves differ from required reserves is unpredictable changes in its reserve balances on the last day of the settement week due to fluctuations in deposit liabilities. In considering the appropriate percentage carryover under CRA, the percentage carryover that would permit individual banks to manage their reserve positions with incomplete information on deposit liabilities should be expanded enough to facilitate reserve management even when unpredictable fluc. tuations in reserve balances occur late in settlement periods. 
Table 4

\section{Errors in Estimating Required Reserves with Incomplete Information about Deposit Liabilities}

\begin{tabular}{|c|c|c|c|c|}
\hline \multirow[b]{2}{*}{$\begin{array}{l}\text { Percentage error } \\
\text { (absolute value) }\end{array}$} & \multicolumn{2}{|c|}{$\begin{array}{l}\text { Percent of banks with he } \\
\text { specified error } \\
\text { on depostinates based }\end{array}$} & \multicolumn{2}{|c|}{$\begin{array}{l}\text { Percent of settlentent weeks in } \\
\text { which banks had the specified } \\
\text { error, for estimates based } \\
\text { on deposit liabilities for }\end{array}$} \\
\hline & $\begin{array}{l}\text { First six days } \\
\text { of each week }\end{array}$ & fist five days & $\begin{array}{l}\text { First six days } \\
\text { of each week }\end{array}$ & $\begin{array}{l}\text { Frst Ive days } \\
\text { of each week }\end{array}$ \\
\hline 2 & 3433 & 76.12 & 231 & 8.46 \\
\hline 3 & 1791 & 46.27 & 0.79 & 3.25 \\
\hline 4 & 10.45 & 2985 & 0.38 & 176 \\
\hline 5 & 8.96 & 23,88 & 0.29 & 0.91 \\
\hline 6 & 597 & 16.42 & 0.20 & 0.56 \\
\hline 7 & 4,48 & 1194 & 0,12 & 0,32 \\
\hline 8 & 299 & 896 & 0.09 & 0.23 \\
\hline 9 & 0,00 & 5.97 & 0.00 & 0,18 \\
\hline 10 & 0.00 & 4.48 & 0.00 & 0,15 \\
\hline
\end{tabular}

This issue was investigated for 67 Eighth District member banks using 1977 data on deposit liabilities. Their total deposits ranged from about $\$ 4$ million to just over $\$ 1$ billion. ${ }^{14}$

Required reserves were calculated for each bank based on deposit liabilities for seven days ending each Tuesday (same as deposit liabilities at the start of business for seven days ending on Wednesdays). Required reserves were estimated for each week based on deposit liabilities for five days ending each Sunday and for six days ending each Monday. Required reserves were estimated by assuming that average deposit liabilities for the whole week would be what they were for the first five or six days of each week. Differences between actual required reserves for each settlement week, based on complete information, and estimated required reserves were calculated as percentages of actual required reserves. Errors in estimating required reserves can be considered maximum errors, since it was assumed that banks have no information on changes in their deposit liabilities near the end of each week, whereas they may have information

14These 67 member banks borrowed from the Federal Reserve during 1977 or early 1978 . The reason for using these banks was that data on their daily deposit liabilities were compiled for another study, and were avalable at no additional cost. If use of data for banks that borrowed from the discount window creates any bias, the errors in estimatirg required reserves would be biased upward; those banks may have borrowed because they had unanticipated reductions in their reserve balances late in some settlement weeks due to dedines in deposit liabilities. The size distribution of the 67 banks is as follows: total deposits of $\$ 0-\$ 10$ million, 9 banks: $\$ 10-\$ 25$ million, $11 ; \$ 25-50$ million, $21 ; \$ 50-100$ million, $8 ; \$ 100-\$ 400$ million, 9 ; and over $\$ 400$ million, 9 . on customer transactions or regular intra-weekly patterns of deposit liabilities that would help them estimate required reserves more accurately.

Results of these calculations, as shown in table 4, indicate that the 2 percent carryover may be too small under CRA. If banks had information on deposit liabilities for only the first five days of each week, 76 percent of them would have estimation errors greater than 2 percent in at least one week. Errors greater than 2 percent would occur in about 8 percent of the settlement weeks. ${ }^{15}$ Only three of the 67 banks, however, had estimation errors greater than 5 percent for two or more settlement weeks in the year, even without information on deposit liabilities for the last two days of each week. This result indi cates that only a few banks that have especially large fluctuations in deposit liabilities would have difficulty in estimating required reserves within approximately 5 percent of actual required reserves using incomplete information.

Even if individual banks occasionally had large errors in estimating their required reserves, those

$\$ 5$ Percentages of settlement weeks in which errors in calculat ing required reserves for the 67 banks were greater than various percentages of actual required reserves are calculated as follows: There were $5 \mathrm{I}$ settlement weeks in 1977. For the 67 banks together there were $3417(67 \times 51)$ settlement weeks. The total number of weeks during the year in which any of the banks had errors of more than 2 percent was 289 based on information about deposit liabilities for the first five days of each week. For the 67 banks as a group, therefore, frrors were greater than 2 percent of required reserves for 8.46 percent ( 289 as a percentage of 3417 ) of the settlement weeks. 
errors should not create significant differences between total reserves and total required reserves for the banking system. Errors by some banks that underestimate their required reserves in a given week would generally be offset by errors of other banks that overestimate their required reserves. The main reason to expect such errors to be offsetting is that banks that have increases in their deposit liabilities late in a settlement week generally receive them from banks having deposit outflows late that same week.

Effects of offsetting errors in calculating required reserves were examined for the 67 member banks mentioned above. Estimates of their required reserves for each week based on deposit information for the first six days were added for all 67 banks, subtracted from the sum of their actual required reserves, and divided by the sum of their actual required reserves. Differences between the sums of estimated and actual required reserves were less than 1 percent of actual required reserves in each settlement week, and the deviations (in absolute value) averaged 0.26 percent. With information on deposit liabilities for only the first five days of each week, the sum of estimated required reserves deviated from actual required reserves by more than 1 percent in only two of the 51 weeks, and deviations for each week averaged 0.37 percent. Since these results are for only a small group of banks, percentage deviations based upon calculations for all banks would be smaller. Permitting banks to carry over more than 2 percent of excess reserves or deficiencies would facilitate reserve management by individual banks under CRA, without affecting substantially the relation between reserves and required reserves for the banking system.

\section{Size of Adustments to Reserve Balances in \\ Response to Changes in Deposit Liabilities}

Costs of monitoring deposit liabilities and estimating required reserves are only two aspects of reserve management by individual banks that are influenced by the timing of reserve requirements. A third aspect is the size of adjustments a bank must make to its reserve balance to avoid excess reserves or deficiencies when its deposit liabilities change. Under CRA, required reserves change during a settlement week in response to changes in deposit liabilities. Considering only the effects of fluctuations in deposit liabil ities on required reserves seemingly implies that adjustments of reserve balances to changes in deposit liabilities would be necessary only under CRA.

However, changes in deposit liabilities have additional effects on the reserve positions of individual banks. A bank that clears checks through its reserve balance at the Federal Reserve has reductions in its reserve balance when its deposit liabilities decline. Suppose the reserve balance of a bank that clears checks through its reserve account initially equals its required reserve balance. Under LRA, a bank must increase its reserve balance by the amount of declines in its deposit liabilities. Under CRA, a bank must increase its reserve balance by some fraction of the decline in deposit liabilities, since required reserves decline as deposit liabilities decline. Therefore, under LRA, a bank that clears checks through its reserve account must make larger adjustments to its reserves per dollar of change in demand deposit liabilities to avoid excess reserves or deficiencies than under CRA.

Under LRA, changes in deposit liabilities during a settlement week do not affect that week's reserves or required reserves for a bank that clears checks through its correspondent accounts. ${ }^{16}$ Conversely, under CRA, required reserves change as deposit liabi:ities change, but for a bank that clears checks through correspondent accounts, reserves are unaffected by changes in deposit liabilities. For that type of bank, therefore, adjustments to reserves necessary to avoid excess reserves or deficiencies are larger under CRA. This conclusion is based upon the assumption that as checks are cleared through a bank's correspondent accounts, its demand balances due from banks change passively in response to changes in its deposit liabilities during each week. Under such a policy, demand balances due from banks decline dollar-for-dollar with reductions in deposit liabilities and increase by the same amount as do deposit liabilities. ${ }^{17}$ transactions accounts and nonpersonal time deposits are subject to nember bank reserve requirements. Member banks must hold their required reserve balances in reserve accounts at Reserve Banks, whereas, nonmernbers may have correspondents hold regtived reserve balances for them in the reserve accounts of their correspondents. Analysis in this section considers reserve adjustments of a bark that clears checks through its correspondent, but holds its required reserve balances in a reserve account at its Reserve Bank. Results for a bank that clears checks through a correspondent and has the correspondent hold its required reserve balances with the Reserve Bank might be substantially different. The terms inder which correspondent banks will offer to hold required reserve balances for nonmembers are not yet known, since reserve requirements will not be imposed on nonmembers until this fall. If correspondents offer this service in a flexible manner, requiring only that demand balances of nonmembers be large enough on average over several weeks or months to compensate the correspondents for services provided and reserve balances held, these nonmernbers might not adjust their cash balances to week-to-week changes in required reserve balances under either CRA or LRA.

17There is evidence that correspondent banks allow respondents this degree of short-term flexibility in cash management. See R. Alton Gilbert. "Access to the Discount Window for All Commercial Banks: Is it Important for Monetary Policy?" this Review (February 1980), p. 19. 
In contrast, if a bank that clears checks through correspondent accounts keeps its demand balances due from banks equal to a fixed proportion of deposit liabilities on a weekly basis, reserve adjustment pressure due to deposit fluctuations would be greater under LRA than under CRA. When deposit liabilities decline, for instance, a bank with such a cash management policy would sell more assets under LRA to meet reserve requirements and to maintain demand balances due from banks equal to a fixed proportion of deposit liabilities; this occurs because required reserves would not decline as deposit liabilities decline. Under CRA, the bank would transfer some of its reserve balances to demand balances due from banks when deposit liabilities decline, since required reserves would also decline in the same week.

This analysis indicates that it is unclear whether adjustments to reserve positions are larger under CRA or LRA. Adjustments by an individual bank to its reserve position in response to given changes in deposit liabilities are analyzed under various assumptions in the Appendix. The largest adjustment occurs for a bank that clears checks through its reserve balance and is subject to LRA. The smallest adjustment (actually zero) results for a bank that clears checks through its correspondent accounts and is subject to LRA. (The latter example assumes that balances due from banks are allowed to fluctuate passively with changes in deposit liabilities.) Under CRA, adjustments to reserve positions are smaller if the bank clears checks through its correspondent accounts, although the advantage of clearing through correspondent accounts in terms of minimizing reserve adjustments would not be as great as under LRA.

\section{Risks due to Changes in Interest Rates}

A final issue concerns the risks that a bank incurs due to delayed effects of changes in demand for bank credit on interest rates under LRA. A bank increases demand deposits of borrowers when it makes additional loans. If borrowers temporarily hold larger demand deposits before making payments, required reserves of the lending bank will be larger in two weeks. When the borrowers withdraw deposits, the lending bank will lose reserves to other banks and must borrow them back through the federal funds market to meet reserve requirements in the current week. A bank that increases its loans may continue to borrow federal funds for several weeks to finance the increase in loans before arranging longer-term financing.

The cost of financing customer loans, therefore, depends upon interest rates two weeks in the future.
A bank that increases loans to its customers will not know immediately whether there is a general increase in demand for bank loans, or whether the increase in demand is limited to its own customers. Therefore, the bank will base the interest rates it charges in the current week on interest rates prevailing up to the current week.

Under LRA, an increase in loan demand would not drive up short-term interest rates in the first week of increased demand. Thus, banks could accommodate the increased loan demand by creating demand deposit liabilities without experiencing reserve deficiencies in the current week. Pressures on interest rates would occur two weeks after the increased loan de mand, when required reserves increase.

If the Federal Reserve kept bank reserves unchanged two weeks after the increase in loan demand, there would be sharp upward pressure on short-term interest rates. Loans that were profitable at the interest rates that prevailed two weeks previously may no longer be profitable because of the increased cost of borrowing reserves.

An increased demand for bank loans has a more immediate effect on short-term interest rates under CRA. As demand deposit liabilities increase, banks begin bidding for additional reserves to meet higher required reserves. These increases in short-term interest rates signal banks that credit demand has risen, and they can adjust their loan terms more quickly.

As stated previously, a primary goal of Federal Reserve policy prior to October 6, 1979 was to moderate fluctuations in short-term interest rates. Effects of this policy on changes in interest rates over two-week periods are shown in table 5. Over a period of 142 weeks from January 1977 through early October 1979, the federal funds rate rose by more than 50 basis points over two-week periods on only five occasions and never rose as much as one percentage point. Banks could accommodate increases in loan demand anticipating that the Federal Reserve would not permit the federal funds rate to rise by more than about 50 basis points during the succeeding two weeks. The Federal Reserve implemented monetary policy under LRA in a manner that minimized interest rate risks to member banks.

Under its new operating procedures adopted in October 1979, the Federal Reserve places less emphasis on stabilizing the federal funds rate and more emphasis on controlling member bank reserves. Consequently, increases in the federal funds rate of more than 50 basis points over two-week periods have been 


\section{Table 5}

\section{Distribution of Changes in the Federal Funds Rate Over Two-Week Periods Before and After October 6, 1979}

\begin{tabular}{|c|c|c|}
\hline \multirow{2}{*}{$\begin{array}{l}\text { Changes in he average } \\
\text { federal funds rate over } \\
\text { perrods of two weeks } \\
\text { (in percentage points) }\end{array}$} & \multicolumn{2}{|c|}{$\begin{array}{l}\text { Percentage or weeks when } \\
\text { changes were hi het } \\
\text { following ranges? }\end{array}$} \\
\hline & $\begin{array}{l}142 \text { weeks } \\
\text { ending } \\
\text { Oelober } 3 \text {. } 1979\end{array}$ & $\begin{array}{l}34 \text { weeks } \\
\text { enolng } \\
\text { May } 28.1980\end{array}$ \\
\hline 2000 or greater & & 1176 \\
\hline 1000 lo 1,099 & & 1765 \\
\hline $075010 \quad 0.990$ & 0070 & 02,94 \\
\hline $0,500,10,0.749$ & 0282 & 0294 \\
\hline $0.25010,0.499$ & 1600 & 0588 \\
\hline 10.100 .10 .0 .249 & 21.83 & $08 \% 2$ \\
\hline $0.05010,0099$ & 14,79 & 0294 \\
\hline 0.00010 .0 .049 & 14.79 & \\
\hline$-0.04910 \quad 0.001$ & 05.60 & \\
\hline 0.099 to -0.050 & 16.20 & \\
\hline-0.249 to 90100 & 64.98 & 05.88 \\
\hline 0.499 10 0,250 & 10070 & 05,86 \\
\hline-0.749 to 0.500 & 00.70 & 0294 \\
\hline $0.0999 .10 \% 0.750$ & & 0588 \\
\hline 1.9998 to 1,000 & & 1176 \\
\hline Below & & 14.71 \\
\hline
\end{tabular}

much more frequent since early October of last year. These results indicate that the Federal Reserve has removed much of the protection that was previously available to banks from effects of changes in shortterm interest rates. Thus, in weighing the advantages of LRA relative to CRA, banks should consider whether they prefer LRA or CRA under a policy of reserve targeting, since the option of reserve management under LRA with the former policy of stabilizing short-term interest rates is no longer available.

\section{CONCLUSIONS}

Under lagged reserve accounting (LRA), required reserve balances of individual banks and the banking system are predetermined each week, based upon deposit liabilities and vault cash two weeks earlier. The Federal Reserve Board expected LRA to reduce the variability of short-term interest rates near the end of reserve settlement weeks. LRA has had the opposite effect, primarily because it contains no mechanism for eliminating excess reserves or deficiencies within the current week that result from fluctuations in total reserves. Under contemporaneous reserve accounting (CRA), which was in effect prior to the adoption of LRA, reactions by banks to excess reserves or deficiencies yielded changes in total required reserves that brought aggregate reserve positions back into equilibrium within the current week.

The major problem for the conduct of monetary policy under LRA is that the Federal Reserve has created reserve balances each week based on deposit liabilities that banks created two weeks previously. In essence, the Federal Reserve has tended to supply reserves to accommodate the growth of bank credit, instead of pursuing an independent monetary policy.

LRA was expected to simplify reserve management of individual banks. It is not possible to draw a general conclusion about the realization of this expectation because several aspects of bank reserve management are affected by the timing of reserve accounting.

A return to CRA would require banks to monitor their deposit liabilities on a more timely basis and to adjust their reserve balances each week in response to changes in the week's deposit liabilities. Some banks may have difficulty calculating their deposit liabilities on a timely basis and would have to estimate their required reserves based on incomplete information. Most banks, however, might be able to estimate their required reserves each week within about 5 percent of actual required reserves even without information on their deposit liabilities for the last one or two days of each settlement week.

Another aspect of reserve management affected by the timing of reserve accounting is the size of adjustments that banks must make to reserve balances in response to changes in deposit liabilities. Banks that clear checks through their reserve accounts at the Federal Reserve must make larger adjustments in their reserves for a given change in demand deposit liabilities under LRA than under CRA. The opposite result obtains for banks that clear checks through correspondent accounts, since adjustments to reserves are smaller under LRA than under CRA.

A final aspect that must be considered concerns risks associated with changing interest rates. Under LRA, changes in interest rates over the succeeding two weeks influence the profitability of investment and lending decisions made by banks in the current week. Moreover, a change in demand for bank credit tends to affect short-term interest rates, with a twoweek lag. Under CRA, changes in demand for bank credit would have more immediate effects on interest rates. In the past, the Federal Reserve minimized these risks by moderating fluctuations in interest rates. 
However, the Federal Reserve has recently permitted larger fuctuations in short-term interest rates in an attempt to control money growth by controlling growth of bank reserves. Consequently, banks are now more vulnerable under LRA to making unprofitable investment decisions due to fluctuating shortterm interest rates. This problem is reduced under CRA.

\section{Appendix: Reserve Adjustments Under CRA and LRA \\ This Appendix analyzes the size of reserve balance adjustments a bank must make to avoid deficiencies caused \\ RESERVE ADJUSTMENT PRESSURE UNDER CRA} by a decline in its demand deposit liabilities under CRA and LRA. At the beginning of a settlement week, the bank holds reserves just equal to its required reserves. During the week, demand deposit liabilities decline, and the bank adjusts its reserve balances to equal required reserves. Feserve adjustments depend on whether the bank is subject to CRA or LRA and on whether it clears cheeks through its reserve account or through accounts at correspondents. ${ }^{1}$

1Results would be symmetrical for an increase in dema.t. deposit liabilities.
A bank's gross demand deposits are assumed to equal $\$ 100$ at the start of business on Thursday (table A1). With demand balances due from other banks of $\$ 5$ and no uncollected funds, net demand deposits equal $\$ 95$. The reserve requirement on net demand deposits is 20 percent and, with $\$ 2$ in vault cash and $\$ 17$ in the reserve balance, total reserves just equal required reserves. By the end of business on Thursday, gross demand deposits decline to $\$ 98$ and remain at that level throughout the week. Because the bank prefers to keep its vault cash equal to 2 percent of its gross demand deposit liabilities,

\section{Table At}

\section{Effects of a Decline in Deposit Liabilities on the Reserves of a Bank}

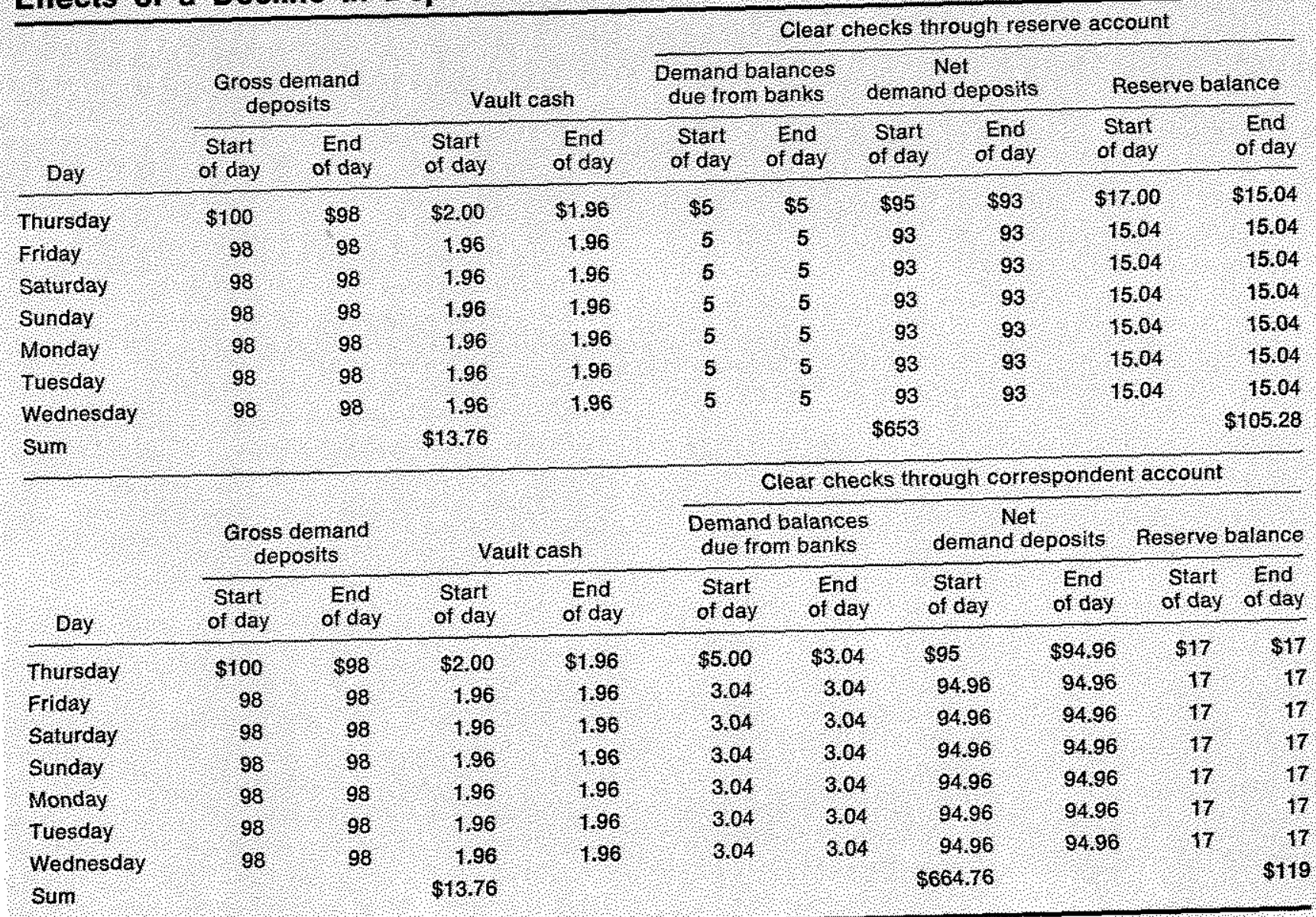


it reduces vault cash to $\$ 1.96$. Given this reduction in gross demand deposits and adjustment to vault cash, the amount by which the bank has to adjust its reserve balance to avoid a reserve deficiency depends primarily on how the bank clears checks.

\section{Clearing Checks through Reserve Balances}

Some banks receive payment for checks deposited with them by depositing the checks with their Reserve Banks for credit to their reserve accounts. When these banks' demand deposit liabilities decline, their reserve balances decline by the same amounts. This response is illustrated in table Al. During Thursday, the bank's reserve balance declines from $\$ 17$ to $\$ 15.04$. That change reflects the $\$ 2$ decline in gross demand deposits and the $\$ .04$ reduction in vault cash, which is deposited in the reserve account. The bank that clears checks through its reserve account is assumed to maintain its demand balances due from other banks at $\$ 5$, since the bank holds those balances for reasons other than clearing checks,

If a bank is subject to CRA and clears checks through its reserve account, the decline in gross demand deposits reduces required reserves and reserve balances. Suppose this bank waits until the last day of the settlement week (Wednesday) to adjust its reserve balance. The magnitude of the adjustment necessary to avoid a reserve deficiency is calculated in table A2. Required reserves are calculated as the sum of required reserves each day of the settlement week. Under CRA, required reserves are based on deposit liabilities at the start of business on Thursday through Wednesday. The sum of net demand deposits is $\$ 653$ and, given a 20 percent reserve requirement, required reserves are $\$ 130.60$. Sum of vault cash over the same period is $\$ 13.76$. The sum of reserve balances at the end of each day over the week would be $\$ 105.28$ without an adjustment to the deposit outflow. Thus, the bank would have to increase its reserve balance on Wednesday by $\$ 11.56$ to avoid a reserve deficiency.

\section{Clearing Checks through Accounts at Correspondents}

Many banks collect checks deposited with them by depositing these checks with their correspondents for credit to their demand balances due from correspondents. For these banks, reductions in deposit liabilities do not affect their reserve balances but reduce their demand balances due from correspondents. In the case presented in table A1, the bank allows its demand balances due from correspondents to decline by the amount of the $\$ 2$ reduction in gross demand deposits. It then deposits $\$ .04$ of vault cash in its demand balances due from correspondents. Thus, net demand deposits are reduced only slightly since the reduction in gross demand deposits is largely offset by the reduction in demand balances due from correspondents.

Calculations in table A2 indicate that the bank would have to increase its reserve balance by only $\$ .192$ on Wednesday to avoid a reserve deficiency. These calculations indicate that, even under the same reserve accounting system (CRA), the magnitude of reserve adjustments
Table A2

Increase in Reserve Balances Necessary to Avoid Reserve Deficiences with a Decline in Deposit Liabilities

\begin{tabular}{|c|c|c|c|c|}
\hline & $\begin{array}{l}\text { Qnen } \\
\text { requ }\end{array}$ & meness & mes & $\begin{array}{l}\text { ged } \\
\text { endents }\end{array}$ \\
\hline & $\begin{array}{l}\text { oleal } \\
\text { ser } \\
\text { Reserve } \\
\text { dceount }\end{array}$ & $\begin{array}{l}\text { hocks } \\
\text { ort } \\
\text { spondre } \\
\text { account }\end{array}$ & $\begin{array}{l}\text { Clear } \\
\text { thro } \\
\text { hesenve } \\
\text { account }\end{array}$ & $\begin{array}{l}\text { cheoks } \\
\text { cont } \\
\text { Corres } \\
\text { spondent } \\
\text { acoount }\end{array}$ \\
\hline vall casl & $\$ 1376$ & $\$ 1376$ & $\$ 1400$ & $\$ 1400$ \\
\hline Reserve balance & 10528 & 11000 & 10528 & 119.00 \\
\hline lolal reserves & 11904 & 13276 & 11928 & 133,00 \\
\hline Regured reserves & 130,60 & 132,952 & 133,00 & 13300 \\
\hline $\begin{array}{l}\text { Duerence between } \\
\text { requred ard }\end{array}$ & 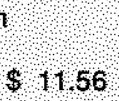 & 192 & s 1372 & 00 \\
\hline
\end{tabular}

differs greatly for banks that clear checks through theit reserve accounts and those that clear checks through correspondent accounts. The important difference is that changes in deposit liabilities change the reserve balances of banks that clear checks through their reserve balances, whereas reserve balances of banks that clear checks through accounts at correspondents are not directly af fected by changes in deposit liabilities.

\section{RESERVE ADJUSTMENT PRESSURE UNDER LRA}

Calculation of reserves and required reserves for a bank subject to LRA requires assumptions about the bank's deposit liabilities and vault cash two weeks earlier. Net demand deposit liabilities are assumed to have averaged $\$ 95$ and vanlt cash to have averaged $\$ 2$ during the settlement period two weeks ealier. Under LRA, therefore, the sum of reserve requirements for each day in the current settlement week is $\$ 133(\$ 95 \times 7 \times 0.20)$, and the vault cash portion of reserves amounts to $\$ 14$ ( $\$ 2 \times 7)$. Therefore, at the start of business on Thursday, reserves equal required reserves.

\section{Clearing Checks through Reserve Balances}

A decline in demand deposits has the same effect on the reserve balance of a bank that clears checks through its reserve balance, whether it is subject to LRA or CRA. Unless the bank adjusts its reserve balance to offset the decline in demand deposit liabilities, the sum of its reserve balances over the current week will be $\$ 105.28$. If subject to LRA, the bank must increase its reserve balance by $\$ 13.72$ on Wednesday to avoid a reserve deficiency. Note that this adjustment is larger than that 
for the bank subject to CRA that clears checks through its reserve account. The decline in demand deposit liabilities has the same effect on reserve balances in both cases, but the adjustment to the reserve balance necessary to avoid a reserve deficiency is smaller for the bank subject to CRA, because its required reserves decline during the current settlement week as demand deposit liabilities decline, whereas, under LRA, required reserves remain unchanged.

\section{Clearing Checks through Accounts at Correspondents}

Changes in deposit liabilities have no effect in the current week on the reserve positions of banks that clear checks through accounts at correspondents. Their required reserves and vault cash portion of reserves are predetermined for the current week, and changes in de- posit liabilities do not directly affect their reserve balances in the current week. Therefore, if such a bank begins a settlement week with its reserve balances just equal to required reserve balances, no adjustment of reserve balances is necessary in the current week to avoid excess reserves or deficiencies in response to changes in deposit liabilities.

\section{SUMMARY}

Effects of returning to CRA on the reserve adjustment pressure on a bank would depend upon how the bank clears its checks. For a bank that clears checks through its reserve account, adjustments to reserve balances for given changes in deposit liabilities would be smaller under CRA. For a bank that clears checks through batances at correspondents, reserve adjustment pressure in response to deposit fluctuations would tend to increase from zero to some relatively small amount.

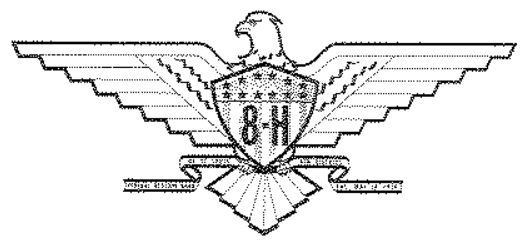

